\title{
Apartment Façade Design Characteristics for Middle and Upper Occupants with Ecological Design Approach
}

\author{
Yoga Pramatatya, Vincentius Totok Noerwasito, and Arina Hayati \\ Department of Architecture, Institut Teknologi Sepuluh Nopember, Surabaya \\ e-mail: totoknoerwasito@gmail.com
}

\begin{abstract}
Social and economic conditions affect people's behavior and preference for housing and the selection of housing area and its design. People with higher economic and social conditions will choose a better quality of housing and the environment. This decision also influences housing preference for apartment design. The quality of the apartment is influenced by a healthy environment, the use of energy that is efficient and can be recycled, using the eco-design approach, and basic facilities are provided. This study focuses on design-based research for designing an apartment building that suits the preferences of middle and upper occupants with an ecological approach. In this study, middle and upper occupant preference determines the shape of the facade design in buildings. In order to determine design parameters and criteria, this study uses a literature review, data analysis, and architectural precedent study. The result finds that several aspects are synthesized and selected as general design criteria apartment buildings. The important parameters in the design of the facade of the building are attractive façade design and emphasize the changing color through vegetation design inside and surrounding the building facades at each season. The building is designed minimalist architecture with a neutral color selection that is combined with natural colors such as wood and stone. Parts of apartment facilities can also be accessed by the occupants easily. Placement of vegetation evenly gives the impression of being close to nature and provides relaxation for each occupant of the apartment building.
\end{abstract}

Keywords-Social Condition, Façade Characteristics, Occupants, Upper-Middle-Class, Apartments, Eco-Design.

\section{INTRODUCTION}

B UILDING design that is accompanied by a discussion in an ecological rotation of an area. The design of a good ecological building has a planning pattern that utilizes nature and is one of the goals in the field of utilization, namely: using natural materials, the building should be directed according to east-west orientation with the north/south receiving natural light without glare, skin (walls and roof) must protect itself from heat, wind, and rain, pay attention to natural air refreshment to save energy use [1].

From the data above, hotel needs for middle and upper occupants are inversely proportional to the increasing number of tourists. then the building design also harms the site ecosystem. Therefore, the design of apartments for middle and upper occupants must be done with an ecological approach. Apartment needs are also influenced by certain groups' lifestyles. The lifestyle of the middle class and upper class can be fulfilled with the addition of facilities in the apartment, the quality of apartment occupancy, and innovation in the facade of low-rise apartment buildings. Architectural design and perception of occupants have a relationship to the decision to choose occupancy, namely aspects of occupancy, occupancy design, quality of occupancy, supporting facilities, and building facade design [2].

The basic theory used as an approach is the ecological approach because, in this context, the two theories need each other. According to survey data released by www.Proudgreenbuilding.com: a new survey of more than 2,800 apartment dwellers in the US shows that 84 percent of respondents said living in a green/sustainable home was important to them, and 85 percent believed that living in a greenhouse / sustainable benefits their health. Architect Ken Yeang goes further by moving balconies or skycourt as interstitial open spaces in buildings for environmental and socio-economic benefits and is an important part of a dense urban environment [3].

Bringing the above elements together produce an initial criterion for designing an apartment that suits behavior of middle and upper occupants with an ecological approach. The theories used as the main theories are the characteristics and behavior of middle and upper occupants, apartment design prinscipal, ecological approaches in architectural design and building facades as other supporting theories and will be explained below:

\section{A. Apartment}

In general, apartments are residential buildings that are separated horizontally and vertically to provide stand-alone dwellings and include low-rise or high-rise buildings, equipped with various facilities that comply with specified standards [4]. Based on the size of the building described in Akmal's book for low-rise apartments are residential buildings with several floors below six floors [5]. This apartment some has an elevator, but other does not have one. This type of apartment is generally preferred by larger families to nuclear families or elderly.

Based on Paul Samuel's research, there are 3 types of apartments based on economic categories, namely: lowerclass apartments, middle-class apartments, and luxury apartments [6]. The difference between the three types of apartments only lies in the size of the space in each residence, and the facilities provided by the apartment. The larger unit size has more facilities available and, more expensive the price per unit of the apartment. The more spacious residential 
The $6^{\text {th }}$ International Seminar on Science and Technology (ISST) 2020

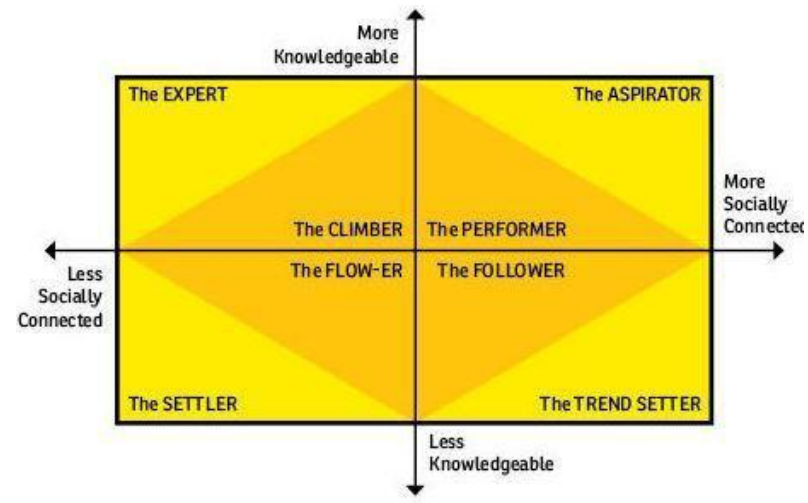

Figure 1. Segmentation Diagram for Middle and Upper Occupants in Indonesia.

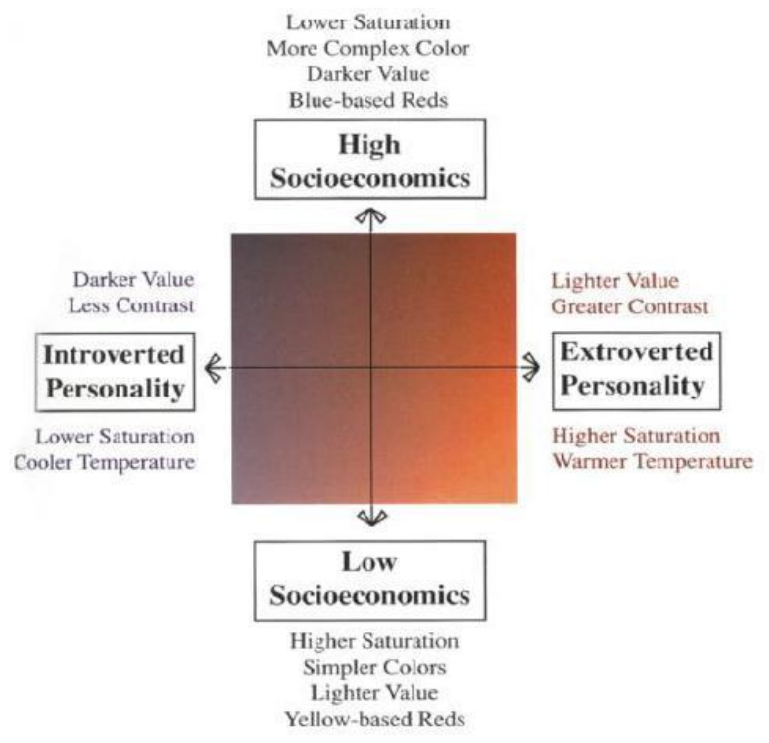

Figure 2. Color psychology in architecture.

units owned, the occupants have more facilities and higher economic support.

Based on Chiara, explained that the floor arrangement system, can be divided into three types, namely; 1) Simplex apartment; 2) Duplex apartment; 3) Triplex apartment. From the above points, it is determined that the apartment residential uses a simplex apartment, which a residential unit is consisted of only one floor so that the number of units can be maximized in one apartment building. The types of unit, namely studio class with a minimum area of $20-35 \mathrm{~m}^{2}$ and class 2 rooms with a minimum area of $30 \mathrm{~m}^{2}$.

\section{B. Ecological Approach to Architectural Design.}

There are various ways that are carried out from an ecological approach to architectural planning, but in general have the same core, design principles with an ecological approach, according to Syarapudin's research, among others; 1) Solutions grow from the place; 2) Design with nature; 3 ) Minimize energy and material usage; 4) Harmonizing the relationship between culture and nature 5) Maintaining environmental aspects such as soil, plants, and so on [7]. In addition to some of the above, Titisari and Hui also explained in Syarapudin's research there are several aspects to the ecological approach, namely; 1) Aspects of structure and construction; 2) Aspects of building materials; 3) Aspects of energy sources and their use in daily life; 4) Aspects of waste

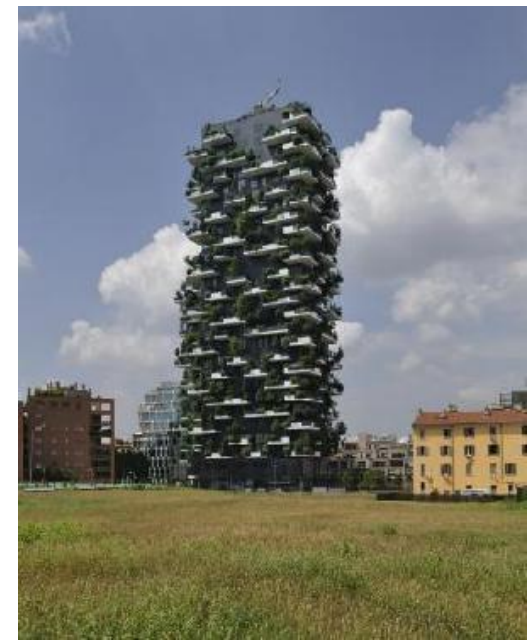

Figure 3. Bosco Verticale.

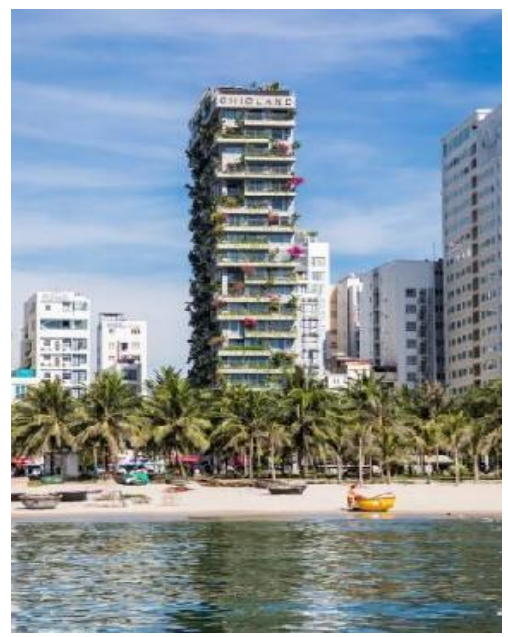

Figure 4. Chicland Hotel.

or utility management; 5) Aspects of space, including zoning, spatial planning, and functions [7].

Widigdo explains that integration of building with ecology can be achieved well, through 3 levels; namely the first physical integration with the local ecological, physical character, including soil conditions, topography, groundwater, vegetation, climate, and so on [8]. Second, is the integration of systems with natural processes, including how to use water, treatment and disposal of liquid waste, the disposal system for buildings and the release of heat from buildings, and so on. The third is the integration of resource use, which includes the sustainable use of natural resources. The application of the three integrations is done in the design of the place of residence.

Measures of physical, social, and economic comfort of occupants, achieved through the use of natural building systems, are emphasized on passive systems, climate control, and harmony with the environment. The shape and orientation of the building are based on harmony with the natural surroundings and the needs of the occupants. To achieve harmony with nature and the comfort of residents technically and scientifically solved [8].

\section{Middle and Upper Occupants}

When going to make a transaction, the occupants of the building will give the decision to buy or not use a product. 
The $6^{\text {th }}$ International Seminar on Science and Technology (ISST) 2020

July $25^{\text {th }} 2020$, Institut Teknologi Sepuluh Nopember, Surabaya, Indonesia

This decision is influenced by the occupant's behavior, and the behavior of residents is also influenced by other factors originating from the surrounding environment or outside the occupant environment. Occupant behavior is defined as the actions of individuals directly involved in the effort to obtain and to use economic goods and services, including the decision process that precedes and determines these actions [9].

According to Karl Max, the middle class tends to be included in the capitalist group because, in reality, this group is a loyal defender of the capitalists. In reality, there are only two classes of society, namely the capitalist or bourgeois group and the proletarian group. In the United States society, the layering of society is divided into six classes, namely; 1) upper-upper class social class; 2) lower-upper class social class; 3) upper-middle-class social class; 4) lower-middleclass social class; 5) upper-lower class social classes; 6) Lower-lower class social class.

In Indonesia, the faces of middle and upper occupants have several types and different characteristics of each type, can see in Figure 1. According to Yuswohady research, to understand the image of the middle class with all its changes, the Middle-Class Institute (MCI) conducted various studies [10]. This research was conducted to find out the lifestyle, values, hopes, life perceptions, behavior, and consumption patterns of the middle class in Indonesia. The survey is designed to reveal the characteristics of Indonesian middleclass people that are worth listening to. According to Yuswohady, are 8 faces of Indonesian middle-class characters, namely:

a. Aspirators have an idealistic character, have goals, also become influencers towards their community. These circles are professionals who are experts in certain fields and have high positions.

b. Actor has the nature of achievement and can use competence and abilities to the maximum but has a selfish nature.

c. Expert, people who are career-oriented and care to continuously improve their expertise in their fields. The negatives are, they don't have much free time but they uphold social and family norms (traditional values).

d. Climber, this character-oriented is economically oriented, takes risks in career, likes to change jobs, wants to take risks in career, has little free time.

e. Trendsetters are people who want to be role models in lifestyle. Always want to be admired in his environment.

f. Followers, this type is very driven by the adjacent environmental conditions. Has low purchasing power trends and difficult trends due to the high purchasing power trends.

g. Flow-er, following technological developments, discussing life flows as it is and upholds spiritual values.

h. Settlers, this group has an economy and finance, but has a negative side that is already in the comfort zone and is anti-improving.

\section{1) Factors Affecting Middle and Upper Occupants}

According to Suryani's book, six factors affect middle and upper occupants and are characteristic of stimuli. 1) A striking difference that will be more attractive to residents; 2)
Innovation or renewal; 3) Intensity, which means intensity in the case of apartments in the form of more facilities and services compared to other apartments; 4) The size is that of the apartment residential unit itself; 5) Movement, residents tend to pay attention to the stimuli that move rather than the silent; 6) Repetition, stimuli that are repeated will attract more attention than those that appear once [11].

In addition to the points mentioned above, other factors affect the occupant of a dwelling, namely color selection on the dwelling. Color is closely related to a person's psychological condition. Color choices can affect the body, mind, emotions, and balance of all three in humans [12]. The use of color in a room is not just a basic element of interior design, because color also has a function and also meaning. More than just aesthetics, color is also able to influence the mood of the occupants. Color related psychology is widely applied in interior design. Selection of the wrong color in the room can cause feelings of discomfort, or even bring adverse effects to psychological conditions [12].

The colors that might suit the characteristics of middle and upper economic dwellers are neutral colors like white. The use of white in the room can give the impression of space and airy into the room. This color is very appropriate to be used for small and narrow spaces to get maximum comfort as shown in the figure 1 [12]. Someone has influenced both personally and universally by the color in their environment. A study has traced certain patterns in color preferences related to age, socioeconomic, and character. The younger a person is, the more likely he is to choose a more saturated color, but as he gets older one will start to prefer lighter and less saturated colors. The diagram in Figure 2 shows how socio-economic and character traits can influence a person's color preference. However, because one cannot influence an individual's personal history concerning color, the designer is forced to design in the direction of the color experience which affects most people in the same way.

\section{2) Middle and Upper Occupants and Ecological Occupancy}

The importance of lifestyle is proposed as an intermediate variable between the translation of socio-demographic characteristics into the determination of occupant preferences because lifestyle is one of the factors that influence consumer behavior. Lifestyle is a characteristic pattern of individual and social behavior of a person or group, usually will be peculiar or eccentric [13]. It is expected that the predictions of the preferences and choices of occupants will be more accurate because lifestyle can close the gap between the sociodemographic variables of the people and aspects of life culture.

In its first AMLI Sustainable Living Index, AMLI surveyed residents about their views on sustainability and green life. The AMLI community includes a series of features for environmentally and health-conscious residents, including; 1) Efficient lighting and equipment; 2) Reducing water consumption in the piping system; 3) Have a community related to the recycling program; 4) Use of native plant footprint to reduce water requirements; 5) Electric car charging station; 6) Bicycle Storage and Repair; 7) Building materials that are low or do not contain VOCs; 8) Good air ventilation; 9) Premium air filter. 
The $6^{\text {th }}$ International Seminar on Science and Technology (ISST) 2020

July $25^{\text {th }}$ 2020, Institut Teknologi Sepuluh Nopember, Surabaya, Indonesia

Table 1.

Synthesis of Theory

\begin{tabular}{|c|c|c|}
\hline \multicolumn{3}{|r|}{ Apartement } \\
\hline No & Points & Synthesis \\
\hline 2 & Description & $\begin{array}{l}\text { Low-level apartments that suit the preferences of middle and upper occupants are dwellings that provide psychological } \\
\text { comfort and provide a place to socialize between residents in dwellings but still have privacy with residents in buildings. In } \\
\text { addition, it needs updating in the design. } \\
\text { a. Expanding family rooms and reducing wall usage. } \\
\text { b. Using minimalist colors on the dwelling } \\
\text { c. Provide space for interaction between building occupants } \\
\text { d. Utilizing vegetation in buildings as a provider of privacy } \\
\text { Ecologycal Approach }\end{array}$ \\
\hline No & Points & Synthesis \\
\hline 2 & Description & $\begin{array}{l}\text { An ecological approach will be achieved if the building design can relate well to the ecosystem on the site and does not hurt } \\
\text { the site from the beginning of development and after development. } \\
\text { a. Using environmentally friendly building materials } \\
\text { b. Minimize the use of cut and fill on the site } \\
\text { c. Utilizing the climate of the site as natural ventilation and natural lighting } \\
\text { d. Provide green open spaces according to local regulations } \\
\text { Middle and Upper Occupants }\end{array}$ \\
\hline No & Points & Synthesis \\
\hline 2 & Description & $\begin{array}{l}\text { There are eight middle and upper-class occupants in Indonesia and each segment has different characteristics and behaviors. } \\
\text { Each segment also has its own positive values and negative values. In general, there are similarities in behavior in each } \\
\text { segmentation that is selfish, has a very busy and monotonous life, and does not do much social interaction within the family } \\
\text { and with the outside environment. They also like freedom, but still have privacy. } \\
\text { a. To overcome selfish behavior in residents, it can be overcome by choosing residential colors that provide a psychological } \\
\text { sense of calm such as white colors combined with natural colors. } \\
\text { b. The behavior of residents who are always busy and lacking social interaction in the family can be overcome by reducing } \\
\text { the walls in the occupancy and expanding the family room. } \\
\text { c. The use of impermeable insulation can provide privacy to the occupants, but the occupancy still feels spacious and } \\
\text { spacious. }\end{array}$ \\
\hline No & Points & $\begin{array}{r}\text { Building Facade } \\
\text { Synthesis }\end{array}$ \\
\hline 2 & Description & $\begin{array}{l}\text { A building facade is the face of a building that is first seen by a prospective occupant or occupant. The building facade } \\
\text { presents a building from the outside to the inside of the building. Therefore, the exploration of facade design greatly } \\
\text { influences the decision of prospective occupants in choosing a housing. } \\
\text { a. The facade is designed attractively and has updates that are tailored to the preferences of middle and upper occupant } \\
\text { b. In addition to having a renewal, the facade can be designed by paying attention to certain patterns and repetitive patterns } \\
\text { on the facade elements such as the arrangement of patterns on the residential balcony } \\
\text { c. The resulting color can be obtained from vegetation that has contrasting colors or from the material in the façade used }\end{array}$ \\
\hline
\end{tabular}

Table 2.

Bosco Verticale Building Precedent Analysis

\begin{tabular}{|c|c|c|}
\hline Process & Analysis & Keyword/statement \\
\hline $\begin{array}{l}\text { Identification of } \\
\text { design forces }\end{array}$ & $\begin{array}{l}\text { In this design, there are several } \\
\text { forces used. The first is urban } \\
\text { expansion, microclimate and } \\
\text { occupant satisfaction }\end{array}$ & $\begin{array}{l}\text { "The Vertical Forest is an anti-sprawl method which helps to control and reduce } \\
\text { urban expansion. In terms of urban density, each tower constitutes the equivalent } \\
\text { of a peripheral area of single family houses and buildings of around 50,000 m2." } \\
\text { Source: www. Archdaily.com } \\
\text { "Unlike "mineral" facades in glass or stone, the plant-based shield does not reflect } \\
\text { or magnify the sun's rays but filters them thereby creating a welcoming } \\
\text { internal microclimate without harmful effects on the environment" } \\
\text { Source: www.stefanoboeriarchitetti.net } \\
\text { "The respondents' main critical remarks concerned the fact that the Bosco Verticale } \\
\text { is a home "for the elite". As Sergio has described: "It is not something for everyone. } \\
\text { It is something for the elite. And the elite has their flaws, from a human point of } \\
\text { view... it is bad." } \\
\text { Source: Max Visser, The Geography of Vertical Forest }\end{array}$ \\
\hline $\begin{array}{l}\text { Propose form- } \\
\text { Refine- Assemble }\end{array}$ & $\begin{array}{l}\text { This building always avoids } \\
\text { mechanical approaches to the design } \\
\text { process. Material selection using } \\
\text { environmentally friendly materials } \\
\text { and structures on the balcony is also } \\
\text { considered because it will function as } \\
\text { a tree planting medium }\end{array}$ & $\begin{array}{l}\text { "The Vertical Forest is an architectural concept which replaces traditional materials } \\
\text { on urban surfaces using the changing polychromy of leaves for its walls. The } \\
\text { biological architect relies on a screen of vegetation, needing to create a suitable } \\
\text { microclimate and filter sunlight, and rejecting the narrow technological and } \\
\text { mechanical approach to environmental sustainability." } \\
\text { Source: www. Archdaily.com }\end{array}$ \\
\hline
\end{tabular}

\section{3) Facilities for Middle and Upper Occupants}

In an apartment building, some important things besides the building design itself is facilities and conveniences store. Apartment preferences report for 2020 released by the National Housing Council (NMHC) and Kingsley Associates in 2019 provides an in-depth understanding at what residents want and need in the apartment. Apartment features and facilities included; 1) Co-working spaces; 2) Fitness and Spa room; 3) Game room; 4) Pet-friendly; 5) Green Spaces; 6) Eco-friendly amenities.

\section{Building Facades}

In the field of architecture, a facade means a face or a front face of a building. The facade is a part that is always first appreciated by the public. Besides that, with this facade media, a picture of the spatial functions that are behind it or inside is obtained. According to Suparno Sastra, a facade is a 
The $6^{\text {th }}$ International Seminar on Science and Technology (ISST) 2020

July $25^{\text {th }} 2020$, Institut Teknologi Sepuluh Nopember, Surabaya, Indonesia

Table 3.

Chicland Hotel Building Precedent Analysis

\begin{tabular}{cl}
\hline \hline Process & \multicolumn{1}{c}{ Analysis } \\
\hline & $\begin{array}{l}\text { In this design, there are several } \\
\text { forces used. The first is to design } \\
\text { sustainable designs and construction } \\
\text { materials that are environmentally } \\
\text { friendly and respond to the needs of } \\
\text { employers related to sustainable } \\
\text { housing. }\end{array}$ \\
design forces
\end{tabular}

This building utilizes vegetation on the balcony to provide control of the hot coastal climate into the residence. Then the selection of materials using natural materials and maximizing the use of glass materials so that occupancy becomes spacious and provides natural lighting in the occupancy
Chicland Hotel is designed to meet requirement of the businessman but doesn't confine architecture itself to the normal commercial style.

Source: http://votrongnghia.com/

"Constructed using environmentally-sensitive indigenous materials, Chicland Danang is the first ecologically friendly hotel in the My Khe Beach . The rooms are made of bamboo, timber, and other renewable resources, not to mention how drop dead gorgeous the space is. This nature-friendly hotel is every Eco-friendly lovers dream." Source: www.designboom.com

VTN architects also says that the vegetation creates a microclimate for the building that makes its interior spaces cooler. the hotel is crowned with an infinity pool, while other facilities include a coffee house with bamboo partitions and a spacious lobby.

Source: www.designboom.com

Taking inspiration from nature and gearing toward nature as the breath, CHICLAND Hotel was built with all rooms having natural light with huge windows from floor to ceiling to feel the wind and fresh air of Da Nang's seaside.

Source: https://www.luxuryhotelawards.com/

"Other vertical facades are covered by a sudden inspirational system of alternate tree pots which is integrated into balconies or sliding part of hotel rooms. That greenery system has a simple design and is easy to operate and maintain."

Source: www.archdaily.com

"The wall are made of concrete as a main material and covered by tropical greenery system. That green facade inspirits for interior design. Furniture and interior materials are made from local or natural material: wood, stone, bamboo, rattan... Guest room is designed with an open restroom connected to bedroom. All guest rooms use maximum glass door system to provide naturae light, view and benefit from greenery facade." Source: http://votrongnghia.com/ visual expression of a building that was first appreciated by the public, therefore the evaluation of the facade is identical to the evaluation of a building [14].

Krier describes the composition of the facade considering functional requirements, namely windows, door openings, sun visors, and the roof plane. The design of the facade is actually related to the creation of a harmonious unity between good proportions, the arrangement of horizontal, vertical structures, the rhythm of materials and entrances, arcades, ground floors, windows, balconies, and roofs. The facade composition consists of structuring on one side and structuring on the other [15].

As a media to give the first impression to architectural work, a facade is a physical media that is first seen by prospective building occupants and the public who pass through the front of the building. Therefore, the facade will cause a lot of shared perceptions of the observed facade. In this study, prospective occupants or residents are more directed and follow the preferences of middle and upper-class occupants who must be highlighted in the building facade. Preferences are specific to facade designs that are designed more creatively because the standards of middle and upperclass residents are different from those of other groups. although it does not rule out the possibility of embodying this preference it can attract the lower classes [15].

According to Suparno Sastra, in terms of appearance, the building can express or give an open impression if the facade of the building is more dominant in the open/transparent part [14]. An open impression of a building can be obtained by using glass material and playing fields that are not too much to create a relationship between the outer space and inner space.

\section{METHOD}

The method used in this research is a literature review and a precedent study. The literature review helps to understand the characteristics of middle and upper occupants, especially in Indonesia, and to identify the preferences of middle and upper occupants of low-level apartment dwellings and their relation to the ecological approach. Then the building precedent that has been reviewed, becomes a parameter for residential buildings that have more or less the same problem. The building precedent that has been reviewed is a precedent with two buildings in Asia and Europe. With these results, it will be known the part of the building to be explored.

\section{A. Literature Review}

A literature review is used as a design approach to help solve existing problems. In this case, the exploration and theories needed are:

1. The theory of low-level apartments to determine the type of occupancy and occupancy area by certain occupants.

2. The theory of the Ecological approach to Architecture design which is the design approach in this design.

3. The theory of middle and upper occupants, to find out the characteristics of middle and upper occupants and their segmentation in Indonesia and what factors affect the occupants in their choice of occupation.

4. Building facade theory which is the main exploration element in responding to problems related to the wishes of residents to move up.

5. The theory of color psychology in architecture to match the color of the dwelling with the characteristics of the occupants in the dwelling.

The way the theoretical study is carried out is not too broad, there must be special specifications to stay focused, namely by paying attention to keywords. The literature study itself has been proven to assist the design process in analytical activities.

\section{B. Precedent Review}

This technique is used to find common design strategies for how to design a residence that is intended for middle and 
The $6^{\text {th }}$ International Seminar on Science and Technology (ISST) 2020

July $25^{\text {th }} 2020$, Institut Teknologi Sepuluh Nopember, Surabaya, Indonesia

upper occupants, from the beginning to the end of the design process. As well as the involvement of the Ecological approach in the residential design is also considered. The design process that is adapted to the character of middle and upper occupants is more complicated, but makes the design most suitable for apartment dwellers.

\section{RESULT AND DISCUSSION}

The design of a building, especially in the building's facade and the design of the occupancy affect the occupants' perception in determining the building. Differences in economic classes in one person also make a difference in designing buildings. The characteristics of middle and upper occupants, in general, are selfish and monotonous life due to busy work. thus impacting social relationships in families that do not have interactions. With the Ecological approach, apartment dwelling should be more comfortable and in accordance with the life and behavior of middle and upper occupants. Table 1 is a detail of synthesis theory:

After theoretical analysis, the next step is to review precedents that have the same problems with middle and upper occupants. Then it will be known how well-known architects design their designs made with the Ecological approach to produce design ideas to achieve goals. Buildings that become precedents, must use a force-based framework in the design process.. Table 2 and Table 3 below are details of precedent synthesis. Design precedent design strategies related to residential for middle and upper occupants with an ecological approach:

\section{A. Bosco Verticale-Boeri Studio}

Precedent 1 Conclussion: Bosco vertical in Figure 3 uses a force-based framework in the design process stage. This building focuses on the microclimate and makes housing suitable for the needs of the upper class. this affects the facade design and the integration of buildings with the environment. The application of vertical forests with certain patterns makes this building an icon of the city of Milan with the color of the facade that changes at certain seasons and the icon of a building that changes the microclimate.

\section{B. Chicland Hotel - VTN Architects}

Precedent 2 Conclussion: Chicland hotel designs residences that suit the needs of the upper-class occupants or entrepreneurs, can see in Figure 4. To meet the needs of the occupants is done with an ecological approach to design. All facilities provided and materials used and building design is designed according to sustainable architectural standards. The building also responds by giving greenery to balconies with certain patterns and large glass to reduce the heat of the coastal climate.

\section{CONCLUSION}

The conclusion of the analysis above is the role of architecture is vital in helping providing satisfaction to middle and upper occupants with facade design. facade design becomes one of the exploration elements that can integrate the characteristics and behavior of residents into architectural concepts that are applied to the facade. Some aspects of architecture that can be affect the middle and upper occupants preference are:(1)The building facade has a balcony which can be a medium for planting vegetation. The structure of the balcony must be strong to accommodate the soil load and vegetation using a balcony with a certain thickness;(2)Façade of the building with vegetation must maintain the privacy of occupants in the residence because the occupants have a character liking freedom. The use of vegetation should not be excessive; (3)Building facades have certain patterns and certain color changes that are not monotonous. In addition to providing a balance between the building and the natural surroundings, it is also to meet the needs of middle and upper-class residents who require an update on the design of the façade; (4)Color pattern on the façade can be produced from the color of vegetation, as applied in two building precedents in design. Colors can also be produced from material colors, but remain with the standard ecological approach.

\section{ACKNOWLEDGEMENT}

This paper is part of the lead author's thesis entitled "Apartment Façade Design Characteristics for Middle and Upper Occupants with Ecological Design Approach" under the supervision of Prof. Dr. Ir. Vincentius Totok N., M.T. and Dr. Arina Hayati, S.T, M.T. This paper has been approved and independently funded.

\section{REFERENCES}

[1] Sukawi, "Ekologi Arsitektur: Menuju Perancangan Arsitektur Hemat Energi dan Berkelanjutan," Universitas Diponegoro Semarang, 2018.

[2] Della Affesia Putri, "Pengambilan Keputusan Konsumen untuk Berinvestasi pada Apartemen dan Perumahan di Surabaya Timur," Institut Teknologi Sepuluh Nopember, 2016.

[3] Pomerey. J, "The Skycourt: A Viable Alternative Civic Space for the $21^{\text {st }}$ Century?," CTBUH Journal, Issue 3, 2007.

[4] Neufert, E, Data Arsitek : Jilid 1, Erlangga, 1980.

[5] Akmal. I, Menata Apartemen, PT. Gramedia Pustaka Utama, 2007.

[6] Paul, Samuel, Apartments: Their Design and Development, Amsterdam, 1967.

[7] Syarapudin, "Pendekatan Arsitektur Ekologi pada Perancangan Kawasan Wisata Danau Lebu Kabupaten Sumbawa Barat," Universitas Brawijaya Malang, 2016.

[8] Widigdo, Wanda, I Ketut Canadama, "pendekatan Ekologi pada Rancangan Arsitektur Sebagai Upaya Mengurangi Pemanasan Global," Universitas Katolik Petra, 2008.

[9] Engal, James F, How to Communite The Gospe; Effectivily, Ghana: Africa Christian Press, 1988.

[10] Yuswohady, Kemal E. Gani, 8 Wajah Kelas Menengah, Jakarta: PT Gramedia Pustaka Utama, 2015.

[11] Suryani, Tatik, Perilaku Konsumen di Era Internet, Yogayakarta: Graha Ilmu, 2013.

[12] Wolfard, Aisyah, "Fungsi dan Pengaruh Warna Terhadap Suasana Hati," Interior Design. [Online]. Available: https://interiordesign.id/psikologi-warna/. [Accessed:17 Juli 2020]

[13] Chaney, D. Lifestyles: sebuah Pengantar komprehensif. Yogyakarta: Jalasutra, 1996.

[14] M. Suparno Sastra. Inspirasi Fasade Rumah Tinggal. C.V Andi Offset, Yogyakarta, 2013.

[15] Arifin, M., \& Samsudin, Karakteristik Fasad Rumah Minimalis di Surakarta. Sinektika 13, 52-61, 2013. 